ORIGINAL ARTICLE

\title{
Sweat rate and fluid turnover in American football players compared with runners in a hot and humid environment
}

\author{
S Fowkes Godek, A R Bartolozzi, J J Godek
}

Br J Sports Med 2005;39:205-211. doi: 10.1136/bjsm.2004.011767

See end of article for authors' affiliations .....................

Correspondence to: Dr Fowkes Godek, Department of Sports Medicine, West Chester University, 214 Sturtzabecker Health Science Center, West Chester, PA 19383, USA sfowkesgod@wcupa.edu

Accepted 9 March 2004

\begin{abstract}
Objectives: To determine sweat rate (SwR) and fluid requirements for American footballers practicing in a hot, humid environment compared with cross country runners in the same conditions.

Methods: Fifteen subjects, 10 footballers and five runners, participated. On the 4th and 8th day of preseason two a day practices, SwR during exercise was determined in both morning and afternoon practices/runs from the change in body mass adjusted for fluids consumed and urine produced. Unpaired $t$ tests were used to determine differences between groups.

Results: Overall SwR measured in litres/h was higher in the footballers than the cross country runners $(2.14(0.53) \vee 1.77(0.4) ; p<0.01)$. Total sweat loss in both morning $(4.83(1.2) \vee 1.56(0.39)$ litres) and afternoon (4.8 (1.2) $v 1.97$ (0.28) litres) practices/runs, and daily sweat losses (9.4 (2.2) $\vee 3.53$ (0.54) litres) were higher in the footballers $(p<0.0001)$. The footballers consumed larger volumes of fluid during both morning and afternoon practices/runs $(23.9$ (8.9) v $5.5(3.1) \mathrm{ml} / \mathrm{min}$ and 23.5 (7.3) v 13.6 (5.6) $\mathrm{ml} / \mathrm{min} ; \mathrm{p}<0.01$ ). For complete hydration, the necessary daily fluid consumption calculated as $130 \%$ of daily sweat loss in the footballers was 12.2 (2.9) litres compared with 4.6 (0.7) litres in the runners $(p<0.0001)$. Calculated 24 hour fluid requirements in the footballers ranged from 8.8 to 19 litres.

Conclusions: The American footballers had a high SwR with large total daily sweat losses. Consuming large volumes of hypotonic fluid may promote sodium dilution. Recommendations for fluid and electrolyte replacement must be carefully considered and monitored in footballers to promote safe hydration and avoid hyponatraemia.
\end{abstract}

A number of articles have reported the physiological responses of endurance athletes exercising in the heat. ${ }^{1-6}$ Some of these studies have been experimental whereas others have reported field observations. ${ }^{124-7}$ In these studies, runners, cyclists, and military personnel make up the largest subject pool. ${ }^{1-3568}$ Heat illness and fluid replacement recommendations are largely based on research involving these populations..$^{8-10}$

Factors that predispose athletes to heat intolerance include a history of heat related problems, drug and alcohol abuse, a high body mass index, obesity, poor aerobic fitness, dehydration, and lack of acclimatisation. ${ }^{8}$ In addition, exercising in heavy clothing or protective equipment increases the risk of heat related disorders as it interferes with heat loss through evaporation, radiation, convection, and conduction. ${ }^{11-13}$ Compared with male participants in soccer, rugby, or lacrosse, and the individual sports of running or cycling, American footballers tend to be larger, not as aerobically fit, and have a higher percentage body fat. $^{14}{ }^{15}$ In addition, as body surface area is larger in footballers, it is reasonable to expect that they have a greater number of sweat glands and therefore may be capable of sweating at higher rates than smaller athletes involved in cross country running. This is especially true of linemen who often weigh 118-145 kg compared with cross country runners who often weigh $65-75 \mathrm{~kg}$. These factors may disadvantage the footballer when it comes to thermoregulation and adequate fluid replacement.

Individual sweat rates vary and depend on factors such as ambient temperature, humidity, air movement, exercise intensity, insulating clothing or equipment, and body size. Sweat rates and fluid turnover have been reported in runners, cyclists, and athletes participating in team sports such as basketball, netball, soccer, and Australian rules football. ${ }^{36} 16-18$ Sweat rates during practice sessions and competitions were
0.985 and 1.209 litres/h for soccer, and 1.371 and 1.601 litres/h for basketball players. ${ }^{16}$ The average sweat rate of $1.71 \mathrm{l} / \mathrm{h}$ in male runners found during a simulated $40 \mathrm{~km} \mathrm{run}^{6}$ compares with the sweat rate range of 1.0-2.5 litres/h common in runners exercising intensely in hot and humid environments. ${ }^{19}$ These studies, however, assessed fluid turnover during a single bout of exercise. If sweat rates in footballers are even higher than those reported in smaller athletes, footballers are challenged to maintain an adequate fluid and electrolyte intake during preseason two a day practices on consecutive days.

A review of the literature reveals a lack of information about fluid turnover in American footballers. The vast majority of information related to heat stress and hydration in athletes involves aerobically trained subjects who are generally much smaller than footballers. Therefore the purpose of this field study was to compare sweat rates, fluid turnover, hydration status, and changes in plasma volume in American footballers and cross country runners during preseason training in a hot and humid environment.

\section{METHODS}

Fifteen subjects, 10 American footballers and five cross country runners ranging in age from 19 to 26 years, volunteered to participate in the study. All subjects were members of National Collegiate Athletic Association division II teams from the same university. Nine of the footballers did little training outdoors during the summer months but participated in off-season training consisting of weightlifting and plyometrics in an air conditioned space with agility drills and speed training in distances of 10-60 yards outside. All five of the runners trained an average of 52 miles a week

Abbreviations: BSA, body surface area; SwR, sweat rate; USG, urine specific gravity 


\begin{tabular}{ll} 
Table 1 & Daily schedule of football team \\
\hline $630 \mathrm{am}$ & Breakfast \\
$830-1045 \mathrm{am}$ & Practice (half pads) \\
$1130 \mathrm{am}$ & Lunch \\
$230 \mathrm{pm}$ & Unit meetings \\
$315-530 \mathrm{pm}$ & Practice (full pads) \\
$630 \mathrm{pm}$ & Dinner \\
$800 \mathrm{pm}$ & Special teams meeting \\
$830 \mathrm{pm}$ & Team/position meetings \\
\hline
\end{tabular}

outside in southeastern Pennsylvania during the hot and humid summer months. Mean (SD) age, height, and mass for the footballers and runners were 21.2 (1.1) years and 22.8 (2.7) years, $188(4.8)$ and $176.3(8.3) \mathrm{cm}$, and 116.63 (16.3) and $71.16(8.9) \mathrm{kg}$ respectively. The study was approved by the university's institutional review board's human subjects subcommittee. All subjects signed consent forms after being fully apprised of the risks involved with the study.

The subjects reported to the human performance laboratory for baseline measurements on day 1 of the football preseason camp. They were instructed to consume at least $500 \mathrm{ml}$ water the night before baseline testing to ensure proper hydration. They reported to the laboratory four times a day on days 4 and 8 of preseason training camp to give blood and urine samples and for data collection related to fluid turnover measurements. The eight day preseason training schedule for the footballers involved practice twice a day, every day except day 7 when they participated in a scrimmage in the morning and did not practice in the afternoon. Generally the football team wore half pads (shorts, shoulder pads, and helmets) for the morning practice and full pads (adding football pants with hip, thigh, and knee pads) for the afternoon practice. Table 1 shows the daily schedule for the football team. The cross country runners continued with their normal training, which consisted of running once or twice a day, every day during preseason.

The first day that the athletes were on campus, height, mass, and body composition were recorded. Body composition was calculated by the skinfold technique using a seven site formula. ${ }^{20}$ Body surface area (BSA) was calculated using height and mass. ${ }^{21}$ Blood samples were collected for baseline measurements of packed cell volume and haemoglobin. Blood samples were obtained using a lancet technique with the subjects standing after they had been upright for a minimum of 30 minutes. Samples were measured in triplicate for packed cell volume (microcapillary technique) and haemoglobin (HemoCue hemoglobin meter; HemoCue Inc, Lake Forest, California, USA), and changes in plasma volume were calculated. ${ }^{22}$ Urine samples were collected to measure specific gravity (USG) by a refractometer, and urine volumes were used to assess urine production during exercise and for sweat rate (SwR) calculations. In separate sessions, maximal oxygen uptake was measured using online, breath by breath, open circuit spirometry $\left(\mathrm{O}_{2}\right.$ analyser model S-3A/1 and $\mathrm{CO}_{2}$
Table 3 Physical and physiological characteristics of footballers and runners

\begin{tabular}{|c|c|c|}
\hline Characteristic & Footballers & Runners \\
\hline Age (years) & $21.2(1.1)$ & $22.8(2.8)$ \\
\hline Height $(\mathrm{cm})$ & $188(4.8)^{*}$ & $176.3(8.9)$ \\
\hline Mass $(\mathrm{kg})$ & $116.6(16.3)^{\star *}$ & $71.2(8.9)$ \\
\hline Surface area $\left(\mathrm{m}^{2}\right)$ & $2.414(0.157)^{\star *}$ & $1.872(0.163)$ \\
\hline Surface area $/$ mass $\left(\mathrm{m}^{2} / \mathrm{kg}\right)$ & $0.0209(0.0017)$ & $0.0264(0.0012)^{* *}$ \\
\hline Body fat (\%) & $17.9(5.5)^{* *}$ & $6.98(1.5)$ \\
\hline Lean body mass (kg) & $95.5(9.6)^{* * *}$ & $66.1(7.8)$ \\
\hline $\mathrm{VO}_{2} \mathrm{MAX}(\mathrm{ml} / \mathrm{kg} / \mathrm{min})$ & $44.7(9.4)^{* * *}$ & $71.3(6.2)$ \\
\hline
\end{tabular}

analyser CD-3A; Applied Electrochemistry; Ametek, Paoli, Pennsylvania, USA) and a graded treadmill test protocol (Q4500; Quinton Ins Co, Bothell, WA, USA).

On the 4th and 8th day of preseason training camp, SwR and fluid turnover data were collected during the athletes' training sessions. SwR in litres/h was calculated using the following formula":

SwR $=$ (pre-exercise body weight - post-exercise body weight + fluid intake - urine volume)/exercise time in hours

This calculation does not account for glycogen and associated water loss during practices. The following protocol was closely followed to collect accurate SwR data:

- Before the practice/run, subjects voided their bladder completely and recorded a nude body weight to the nearest quarter pound.

- The subjects dressed and reported directly to the fields for practice and training.

- Water was carefully pre-measured into individually labelled 2 litre bottles and kept on ice in three separate coolers marked offence, defence, and runners.

- The coolers were easily accessible to the athletes and continuously monitored by the researchers.

- The subjects were encouraged to drink frequently.

- The subjects were instructed to drink only from their water containers and not to let any water fall to the ground.

- The subjects had access to on-field watering fountains to cool themselves but did not drink from them.

- None of the subjects urinated during their respective exercise bouts.

- After practice, each subject returned directly to the locker room with instructions not to drink and to briefly shower and towel dry.

- The subjects immediately returned to the laboratory, voided completely, and recorded a post-exercise nude body weight.

- Each subject's post-practice urine volume was accurately measured and recorded.

Table 2 Temperature and relative humidity during practices/runs for days 4 and 8

\begin{tabular}{|c|c|c|c|c|c|c|}
\hline \multirow[b]{2}{*}{ Time of day } & \multicolumn{3}{|l|}{ Day 4} & \multicolumn{3}{|l|}{ Day 8} \\
\hline & $\overline{\mathrm{DB}}\left({ }^{\circ} \mathrm{C}\right)$ & RH (\%) & WB $\left({ }^{\circ} \mathrm{C}\right)$ & $\mathrm{DB}\left({ }^{\circ} \mathrm{C}\right)$ & RH (\%) & WB $\left({ }^{\circ} \mathrm{C}\right)$ \\
\hline $835 \mathrm{am}$ & 26.1 & 71 & 23.9 & 27.2 & 68 & 22.8 \\
\hline $945 \mathrm{am}$ & 27.8 & 68 & 22.8 & 29.4 & 62 & 23.9 \\
\hline $1030 \mathrm{am}$ & 30 & 63 & 24.4 & 31.1 & 58 & 25 \\
\hline 335 pm & 33.8 & 47 & 23.9 & 33.9 & 38 & 23.3 \\
\hline $430 \mathrm{pm}$ & 34.4 & 44 & 25 & 35 & 36 & 23.3 \\
\hline $525 \mathrm{pm}$ & 33.3 & 44 & 23.9 & 33.9 & 38 & 23.3 \\
\hline
\end{tabular}


Table 4 Fluid turnover in footballers and cross country runners during practices/runs

\begin{tabular}{|c|c|c|c|c|c|c|c|c|}
\hline & Sport & $\begin{array}{l}\text { Weight loss } \\
\text { (kg) }\end{array}$ & $\begin{array}{l}\text { Sweat loss } \\
\text { (litres) }\end{array}$ & $\begin{array}{l}\text { Fluid consumed } \\
\text { (litres) }\end{array}$ & $\begin{array}{l}\text { Fluid consumed } \\
\text { (ml/min) }\end{array}$ & Urine volume (ml) & $\begin{array}{l}\text { Urine volume } \\
\text { (ml/min) }\end{array}$ & $\begin{array}{l}\text { Sweat rate } \\
\text { (litres/h) }\end{array}$ \\
\hline \multirow[t]{2}{*}{ Morning } & $\mathrm{FB}$ & $1.71(0.9)$ & $4.83(1.2)$ *** & $3.23(1.2)^{\star * *}$ & $23.9(8.9)^{* * *}$ & $105.9(40.2)$ & $0.8(0.3)^{*}$ & $2.15(0.56)^{*}$ \\
\hline & $\mathrm{CC}$ & $1.35(0.3)$ & $1.56(0.4)$ & $0.33(0.19)$ & $5.5(3.1)$ & $119.2(105.7)$ & $1.99(1.7)$ & $1.56(0.4)$ \\
\hline \multirow[t]{2}{*}{ Afternoon } & $\mathrm{FB}$ & $1.69(0.85)$ & $4.76(1.2)^{\star \star \star}$ & $3.19(0.98)^{* * *}$ & $23.5(7.3)^{*}$ & $112.2(32.1)^{\star *}$ & $0.83(0.24)$ & $2.12(0.53)$ \\
\hline & $\mathrm{CC}$ & $1.21(0.18)$ & $1.97(0.28)$ & $0.82(0.36)$ & $13.6(5.6)$ & $57.1(42.4)$ & $0.95(0.71)$ & $1.97(0.28)$ \\
\hline \multirow[t]{2}{*}{ Daily mean rates } & $\mathrm{FB}$ & - & - & - & $23.73(8.03)^{*}$ & - & $0.82(0.27)^{*}$ & $2.14(0.53)^{*}$ \\
\hline & $\mathrm{CC}$ & - & - & - & $9.55(6.24)$ & - & $1.47(1.4)$ & $1.77(0.4)$ \\
\hline \multirow[t]{2}{*}{ Daily totals } & $\mathrm{FB}$ & $3.4(0.95)$ & $9.4(2.2)^{* * *}$ & $6.42(1.7)^{\star * *}$ & - & $109.06(35.96)$ & - & \\
\hline & $\mathrm{CC}$ & $2.56(0.34)$ & $3.53(0.54)$ & $1.15(0.53)$ & - & $88.17(84.38)$ & - & \\
\hline
\end{tabular}

Data are mean (SD). Daily totals is during practices/runs.

Significantly higher than in cross country runners, ${ }^{*} p<0.01,{ }^{* *} p<0.001,{ }^{* * *} p<0.0001$.

$\mathrm{FB}$, American football; CC, cross country running.

- Water that remained in each bottle was measured and subtracted from the starting volume to calculate fluid consumed during each exercise session.

Football practices began at 830 am and $315 \mathrm{pm}$ and lasted 2.25 hours including 15 minutes of stretching before the actual start of practice. The stretch period was included in the SwR calculations as it was hot and humid, and the players were sweating while they were stretching. The cross country athletes performed two separate exercise bouts each day beginning at $900 \mathrm{am}$ and $400 \mathrm{pm}$. Dressed in shorts, shoes, and socks, they ran around the fields where the football team was practicing so that they were exercising under the same environmental conditions. The exercise time period for the runners totalled 60 minutes, which included a five minute warm up, two 25 minute continuous runs separated by about two minutes for fluid replacement and data collection related to a separate study, and a three minute warm down period.

Estimated fluid replacement requirements were calculated as $130 \%$ of the fluid lost through sweating during the exercise bouts. This was based on current research and fluid replacement recommendations and guidelines, which suggest the replacement of $25-50 \%$ more than sweat losses to account for obligatory losses in urine, respiration, and sweating.9 ${ }^{23}$ Fluid replacement after practices/runs was calculated as $130 \% \times$ sweat loss during exercise - fluid consumed during practice/run.

Independent $t$ tests were used to determine differences in physical characteristics, SwR, sweat loss, fluid consumption, estimated fluid replacement requirements, changes in plasma volume, urine production, and USG between footballers and runners. The level of significance was set at $\mathrm{p}<0.05$.

\section{RESULTS}

The average on-field temperatures and relative humidity during morning and afternoon practices were $28.4^{\circ} \mathrm{C}$ and $64.9 \%$, and $34.5^{\circ} \mathrm{C}$ and $43 \%$ respectively; see table 2 for details.

The average running speed of the cross country athletes approximated a 650 mile $(415 \mathrm{~km})$, whereas the footballers exercised intermittently during the practice sessions and were inactive for a considerable amount of time. It is estimated that the footballers were exercising for about 20 minutes out of every hour. Table 3 presents the physical characteristics of the footballers and cross country runners. Height, mass, BSA, percentage body fat, and lean body mass were all higher in footballers than cross country runners, whereas surface area/weight ratios and $\mathrm{VO}_{2} \mathrm{MAX}$ were lower in footballers than in runners.

During the two days of data collection, three footballers missed a total of four practices because of injury, and one runner missed one day and two practices. Data from these athletes on these occasions were not included in the statistical analysis. All data are presented as means (SD).

Table 4 presents the fluid turnover data for the footballers and cross country runners. Total sweat loss and fluid consumption were higher in the footballers during both morning and afternoon practices which was expected because football practice lasted for 2.25 hours and the runners exercised for one hour. Fluid consumption was calculated in $\mathrm{ml} / \mathrm{min}$ to account for the differences in exercise duration. However, the rate of fluid consumption was still higher in the footballers than the cross country runners during both morning and afternoon sessions. The footballers were consistent in fluid consumption during morning (23.9 (8.9) $\mathrm{ml} / \mathrm{min}$ ) and afternoon (23.5 (7.3) $\mathrm{ml} / \mathrm{min})$ practices. However, the runners consumed 5.5 (3.1) $\mathrm{ml} / \mathrm{min}$ during the morning runs compared with $13.6(5.6) \mathrm{ml} / \mathrm{min}$ during the afternoon runs $(\mathrm{p}<0.05)$. Fluid consumption for the footballers ranged from $9.5 \mathrm{ml} / \mathrm{min}(570 \mathrm{ml} / \mathrm{h})$ to $42.3 \mathrm{ml} / \mathrm{min}$ $(2538 \mathrm{ml} / \mathrm{h})$. Urine volumes in $\mathrm{ml} / \mathrm{min}$ were significantly lower in the footballers during morning practices than in the runners, and the daily average rate of urine production during both practices was less than that of the runners (table 4).

SwR was higher in the footballers than the runners during the morning practices/runs and overall SwR, which included all of the data from the four practice/runs (table 4). The mean SwR in footballers $(\mathrm{n}=36)$ was $2.14(0.53) \mathrm{l} / \mathrm{h}$ compared with $1.77(0.4) \mathrm{l} / \mathrm{h}$ in the runners $(\mathrm{n}=18)(\mathrm{p}<0.01)$. After adjustment for BSA, overall SwR during all four exercise sessions was not different between the groups. SwR was

Table 5 Estimated fluid requirements for maintaining body fluid balance

\begin{tabular}{llll}
\hline Sport & $\begin{array}{l}\text { Estimated fluid replacement between } \\
\text { morning and afternoon practice/runs (litres) }\end{array}$ & $\begin{array}{l}\text { Estimated fluid replacement before } \\
\text { the next morning practice/run (litres) }\end{array}$ & $\begin{array}{l}\text { Estimated } 24 \text { hour fluid requirements } \\
\text { to maintain fluid balance (litres) }\end{array}$ \\
\hline FB & $3.050(1.07)^{*}$ & $2.998(1.06)^{*}$ & $12.23(2.91)^{* *}$ \\
CC & $1.693(0.49)$ & $1.714(0.211)$ & $4.578(0.705)$ \\
\hline
\end{tabular}

Estimation based on $30 \%$ more than sweat loss (mean (SD)).

Significantly higher than in cross country runners, ${ }^{*} p<0.01$, ${ }^{* *} p<0.0001$.

$\mathrm{FB}$, American football; CC, cross country running. 


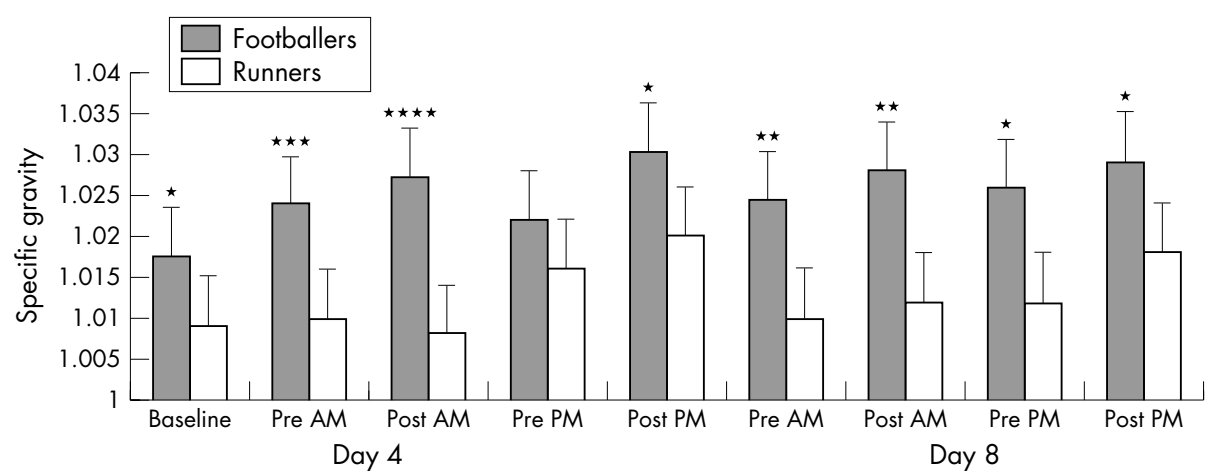

Figure 1 Urine specific gravity in American football players and cross country runners. Values are mean (SD). Pre AM, Before morning practice/run; Post AM, after morning practice/run; Pre PM, before afternoon practice/run; Post PM, after afternoon practice/run. Significantly higher than in cross country runners, ${ }^{*} p<0.05,{ }^{* *} p<0.01,{ }^{* * *} p<0.001,{ }^{* * * *} p<0.0001$.

872.2 (193.6) $\mathrm{ml} / \mathrm{m}^{2} / \mathrm{h}$ in the footballers compared with 948.2 (181.3) $\mathrm{ml} / \mathrm{m}^{2} / \mathrm{h}$ in the cross country runners. Although there were also no differences in SwR between the groups during the morning sessions, afternoon SwR in the cross country runners $\left(1059(90.2) \mathrm{ml} / \mathrm{m}^{2} / \mathrm{h}\right)$ was higher than in the footballers $\left(867(188.9) \mathrm{ml} / \mathrm{m}^{2} / \mathrm{h}\right)(\mathrm{p}<0.01)$. A wider range of SwR was seen in the footballers (1.1-3.6 litres/h or 488$\left.1353 \mathrm{ml} / \mathrm{m}^{2} / \mathrm{h}\right)$ than in the cross country runners $(1.04-$ 2.49 litres $/ \mathrm{h}$ or $650-1234 \mathrm{ml} / \mathrm{m}^{2} / \mathrm{h}$ ).

Estimated fluid replacement requirements for the footballers were higher than those for the runners between morning and afternoon practices/runs and between afternoon practices and the next morning practice (table 5). Fluid requirements based on $130 \%$ of total daily sweat losses indicated that to maintain fluid balance, the average footballer was required to consume 12.23 (2.9) litres a day compared with $4.58(0.7)$ litres a day in runners $(\mathrm{p}<0.0001)$. The range of daily fluid requirements was very large in the footballers (8.8-19.3 litres), especially when compared with the runners (3.6-6 litres).

USG was higher in footballers than in runners at every time measured, except before the afternoon practice/run on day 4 (fig 1). Independent $t$ tests ranged from $t=2.225, \mathrm{p}=$ 0.044 (baseline) to $t=6.01, \mathrm{p}<0.001$ (after the morning practice on day 4). Of particular note, USG in footballers was higher than in runners before morning practice on day 4 $(t=3.18, \mathrm{p}=0.007)$, morning practice on day $8(t=3.87$, $\mathrm{p}=0.0019)$, and afternoon practice on day $8(t=2.67$, $\mathrm{p}=0.019)$, indicating that footballers often began practice inadequately hydrated.

Changes in plasma volume during practices and runs were consistently different between the groups (fig 2). Packed cell volume and haemoglobin assessed 10-15 minutes after practice indicated haemoconcentration in the footballers and haemodilution in the runners. Data from all four exercise sessions indicated that, on average, plasma volume declined during exercise by $5 \%$ in the footballers but expanded by $3.8 \%$ in the runners $(\mathrm{p}<0.01)$.

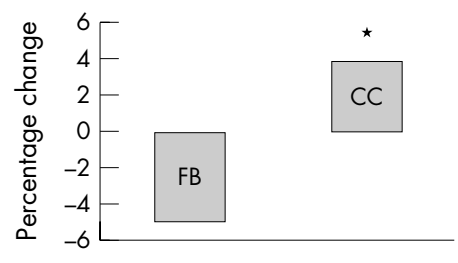

Figure 2 Change in plasma volume in American football players (FB) and cross country runners (CC) during practices/runs. *Significantly different from the footballers, $\mathrm{p}<0.01$.

\section{DISCUSSION}

SwR in footballers performing intermittent exercise during practice was higher than that of athletes running continuously in the same environmental conditions. Although making direct comparisons is difficult because of the different exercise intensities inherent in different sports, it is important to discuss SwR reported in other groups of athletes. The average SwR of 1.77 litres/h in our runners is nearly identical with the 1.71 litres/h reported in male runners during a $40 \mathrm{~km}$ run in similar environmental conditions. ${ }^{6}$ In soccer players, SwR during games played in the heat ranged from 1.2 litres $/ \mathrm{h}^{16}$ to 1.67 litres/h. ${ }^{24}$ SwR in basketball players competing indoors in ambient temperatures of $20^{\circ} \mathrm{C}$ was 1.6 litres $/ \mathrm{h},{ }^{16}$ and Pyke and $\mathrm{Hahn}^{18}$ reported SwR averaging 1.8 litres/h in rugby players competing in ambient temperatures of $38^{\circ} \mathrm{C}$. The average SwR of over 2.1 litres/h (range 1.1-3.6) in our footballers is notably higher than other athletes studied in similar conditions. Furthermore, SwR was higher than 2.25 litres/h in five footballers on 12 different occasions, and $\geqslant 3$ litres/h in two players on three occasions. Conversely, a SwR of 2.25 litres/h was exceeded only three times in the runners, and the highest SwR was 2.4 litres/h.

Important factors that affect sweat production during exercise are physical conditioning (aerobic and anaerobic), acclimatisation, hydration status, exercise intensity, physical size, and amount of clothing or equipment worn. The first four factors should have favoured a higher SwR in the runners as they were aerobically trained, acclimatised, hydrated, and exercised continuously at a high intensity. ${ }^{25-28}$ This leaves differences in physical size (BSA) and the amount of clothing and equipment worn as plausible explanations for the higher SwR in footballers

After adjustment for BSA, SwR was not different between the footballers and the runners. Using a stepwise multiple regression technique, Havenith and van Middendorp ${ }^{29}$ showed that total body sweat loss is highly dependent on BSA. They reported that sweat loss was $50 \%$ dependent on body size (surface area or mass) and much less dependent on physical fitness. Therefore the higher SwR seen in the footballers can be partially explained by a greater number of sweat glands. This is further supported by data on basketball players with a mean BSA of $2.27 \mathrm{~m}^{2}$ who sweated at a rate of over 1.6 litres/h in moderate environmental conditions $\left(20^{\circ} \mathrm{C}\right) .{ }^{16}$ The SwR of the larger basketball players was higher than that reported in soccer players and runners with BSA of $1.97 \mathrm{~m}^{2}$ and $1.92 \mathrm{~m}^{2}$ respectively, who were exercising in more extreme conditions. ${ }^{6}{ }^{16} \mathrm{~A}$ BSA of over $2.4 \mathrm{~m}^{2}$ in our footballers compared with $1.87 \mathrm{~m}^{2}$ in our runners probably accounted for some of the SwR differences 
between groups. Although adjustment for BSA is useful for making comparisons with other populations, the important point is that overall sweat production in litres/h was higher in the footballers. This difference may be critical when considering the fluid replacement needs of these athletes.

The high SwR noted in the footballers can also be partially attributed to the equipment. Mathews et al ${ }^{12}$ showed significantly higher weight loss in subjects wearing full football equipment than in those wearing only shorts but carrying weight equal to that of the equipment. Wearing heavy protective clothing has been shown by others to decrease the time of onset of sweating and to increase SwR. ${ }^{30}$ The effect of the equipment was apparent in our footballers, who were noticeably sweating while they were stretching before practice. Although it was hotter but less humid in the afternoons, the wet bulb conditions and resultant heat stress were similar in each of the four practices (table 2). Whereas the footballers consistently sweated at a rate that exceeded 2.12 litres/h, SwR in the runners was 1.56 litres/h in the morning compared with 1.97 litres/h in the afternoon.

Total sweat loss during both morning and afternoon practices/runs and daily sweat losses (9.4 $v 3.5$ litres) were all higher in footballers. The considerable difference in fluid loss during exercise is partially explained by the fact that football practices were over twice as long as the runs, although the actual time spent in vigorous activity was less. However, sweat losses of 9.4 litres a day (range 7.1-14.8) are important to consider. Even though the footballers consumed fluids at a faster rate during exercise than the runners (23.7 v $9.6 \mathrm{ml} / \mathrm{min}$ ), they still had to replace large volumes of fluid between practices. The average fluid consumption by footballers during practice was over 3 litres. However, based on fluid replacement guidelines, they needed to consume an additional 3 litres before the next practice. Fluid intake in footballers varied tremendously ranging from 1282 to $5712 \mathrm{ml}$ per practice, or 570 to $2539 \mathrm{ml} / \mathrm{h}$. The average fluid intake in our runners of $575 \mathrm{ml} / \mathrm{h}$ was similar to those reported in male soccer players. ${ }^{16}$ Broad et al reported fluid intakes of $429 \mathrm{ml} / \mathrm{h}$ and $516 \mathrm{ml} / \mathrm{h}$ in male soccer players and $797 \mathrm{~m} / \mathrm{h}$ and $1079 \mathrm{ml} / \mathrm{h}$ in male basketball players during practices and competitions respectively. ${ }^{16}$ Our footballers consumed $1425 \mathrm{ml} / \mathrm{h}$, suggesting that larger athletes (footballers and basketball players) who are exercising intermittently can comfortably ingest higher volumes than previously reported in smaller athletes (runners and cyclists) performing continuous exercise. ${ }^{31}$

It appears that large athletes replace fluids at rates that exceed recommendations for the average $70 \mathrm{~kg}$ man (some as high as $2500 \mathrm{ml} / \mathrm{h}$ ). However, the footballers still lost $1.7 \mathrm{~kg}$ per practice, which can be partially attributed to a loss of glycogen stores and its associated water. Regardless of position, footballers have been shown to have a high percentage of fast twitch fibres ranging from $61.3 \%$ to $71.2 \%$. Lactate concentrations and glycogen depletion patterns indicate that playing football involves strenuous intermittent activity, which promotes high glycogen use. ${ }^{32}$ It is also likely that the footballers were not completely replacing sweat losses. USG was always higher after than before practice, suggesting that they were dehydrated after practice sessions.

The footballers appeared to be attentive to drinking during practices, but high volume fluid replacement (570-2539 ml/h) also raises the question of consuming too much hypotonic fluid. ${ }^{33}{ }^{34}$ We have never seen a case of acute hyponatraemia (serum sodium $<130 \mathrm{mEq} / \mathrm{l}$ ) in footballers. However, we have observed mild and symptomatic sodium depletion ( sodium $=132-135 \mathrm{mEq} / \mathrm{l}$ ) usually after several days of preseason practice (clinical observations of symptoms such as nausea, fatigue, headache, and muscle twitching verified by
What is already known on this topic

- Average sweat rates in non-football athletes exercising in a hot environment range from 0.5 to 1.75 litres/h.

- Generally athletes do not tolerate gastric volumes in excess of $600-800 \mathrm{ml}$.

- Fluid replacement recommendations suggest that athletes consume fluids in volumes of $100 \%$ to up to $150 \%$ of sweat losses.

\section{What this study adds}

- Average sweat rates of American footballers wearing equipment and practicing in the heat are consistently over 2.0 litres/ $h$.

- High sweat rates may be explained not only by the protective barrier of equipment but a larger body surface area, which may indicate larger or a greater number of sweat glands.

- Large athletes such as American footballers who exercise intermittently can comfortably consume high volumes of fluid (500-2500 ml/h) during practices.

- Following fluid replacement recommendations, the footballers would be required to consume 8.8-19 litres a day, potentially promoting hyponatraemia.

blood electrolyte analyses in our laboratory). The low blood sodium concentrations are probably explained by consumption of large volumes of hypotonic fluids combined with inadequate dietary sodium intake during the preseason.

Based on estimated sodium losses and fluid consumption needs exceeding 12 litres a day (ranging from 8.8 to 19.3 litres a day), the electrolyte content of the rehydration fluids used for footballers should be considered. The most common fluids consumed during football practices are water and hypotonic carbohydrate and electrolyte drinks. Although sweat electrolytes were not measured in our study, the possibility of sodium depletion exists with the high volume sweat losses observed in the footballers. Sweat sodium can range from 20 to $80 \mathrm{mmol} / \mathrm{l}^{35}$ and in professional footballers was recently found to range from $68 \mathrm{mmol} / \mathrm{l}$ (unpublished data) to as high as $110 \mathrm{mmol} / \mathrm{l}^{36}$ With sweat losses of 9.4 litres a day at a concentration of $50 \mathrm{mmol} / \mathrm{l}$, over $10 \mathrm{~g}$ sodium would be lost in our average footballer and would range from 8.165 to over $17 \mathrm{~g}$ a day. Therefore footballers must understand that sodium replacement between practices and at meals is critical for maintaining electrolyte balance, especially with high volume sweat losses over successive days. Armstrong et $a^{30}$ suggested sodium and $\mathrm{Ca}^{2+}$ supplementation when exercise is performed in protective overgarments for six hours in the heat, and the sweat losses of their subjects were less than those of our footballers.

Except for a single measurement, USG was higher in the footballers than the runners and consistently exceeded 1.020, even before practices. Chronic dehydration in footballers during the preseason could be expected, with average sweat losses of 9.4 litres a day and fluid requirements of over 12 litres a day. It may be unrealistic to expect adequate rehydration and fluid retention in large athletes practicing for 4.5 hours a day, particularly if sodium is not adequately replaced. 
The percentage change in plasma volume during exercise was also different between the groups. Although conflicting observations and conclusions are reported in the literature as to what happens to plasma volume when subjects exercise under thermal stress, there is some consensus that these differing results are probably due to differences in experimental procedures and protocols. ${ }^{37}$ Certainly, physical fitness, hydration status, acclimatisation, posture when blood samples are taken, and the type of exercise performed by the subjects affect plasma volume responses. Haemoconcentration occurs when exercise is performed in a supine or seated position (cycling) whereas haemodilution is often reported during upright exercise such as bench stepping or running, although results are widely variable. ${ }^{37}$ Even with considerable variation within our groups, we detected a significant difference between the runners and the footballers. We observed haemodilution (plasma volume expansion) in the runners and haemoconcentration (a contracted plasma volume) in the footballers. These differences may be attributed to differences in aerobic fitness or acclimatisation, but may be due to inadequate fluid replacement in the footballers compared with the runners. It is also possible that the different postures inherent in the two activities may have contributed to our findings.

In summary, footballers have a greater percentage body fat and BSA, but a smaller surface area/mass and lower aerobic fitness than runners. In addition, SwR measured in litres/h in footballers exercising intermittently was higher than in runners who ran continuously in the same environmental conditions. The most likely explanation for this is the combination of BSA and equipment. Footballers lose a tremendous volume of fluid due to sweat loss during preseason training, which may be difficult to replace on a daily basis. During exercise, footballers consumed fluids at rates that exceeded runners and published guidelines. However, fluid deficits were still present before the next practice session, and additional fluid replacement may be needed between practices. Using current guidelines, footballers required an average daily fluid intake of 12 litres. Fluid volumes of this magnitude would be difficult to ingest and could cause hyponatraemia if sodium replacement is not factored into the dietary needs of the players. Chronic dehydration may occur in footballers if fluid and sodium are not adequately replaced between practice sessions. Current recommendations for fluid and sodium consumption based on research involving non-football athletes may need to be modified for footballers.

\section{Authors' affiliations}

S Fowkes Godek, J J Godek, West Chester University, West Chester, PA, USA

A R Bartolozzi, Pennsylvania Hospital, Philadelphia, PA, USA

Competing interests: none declared

\section{REFERENCES}

1 Armstrong LE, Costill DL, Fink WJ. Influence of diuretic-induced dehydration on competitive running performance. Med Sci Sports Exerc 1985; 17:456-61.

2 Armstrong LE, Hubbard RW, Jones BH, et al. Preparing Alberto Salazar for the heat of the 1984 Olympic Marathon. Phys Sportsmed 1986:3:73-81.

3 Leiper J B, Pisiladis Y, Maughan RJ. Comparison of water turnover rates in men undertaking prolonged cycling exercise and sedentary men. Int J Sports Med $2001 ; 22: 181-5$.

4 Marino FE, Mbambo Z, Kortekaas E, et al. Advantages of smaller body mass during distance running in warm, humid environments. Eur $J$ Physiol 2002;441:359-67.

5 Millard-Stafford MPB, Sparling LB, Rosskopf BT, et al. Carbohydrateelectrolyte replacement during a simulated triathlon in the heat. Med Sci Sports Exerc 1990;22:621-8.

6 Millard-Stafford MPB, Sparling LB, Rosskopf BT, et al. Fluid intake in male and female runners during a 40-km run in the heat. J Sports Sci 1995; 13:257-63.

7 Gardner JW, Kark JA, Karnei K, et al. Risk factors predicting exertional heat illness in male Marine Corps recruits. Med Sci Sports Exerc 1996;28:939-44.
8 Binkley H M, Beckett J, Casa DJ, et al. National athletic trainers' association position statement: exertional heat illnesses. J Athl Train 2002;37:329-43.

9 Casa DJ, Armstrong LE, Hillman SK, et al. National athletic trainers' association position statement: fluid replacement for athletes. J Athl Train 2002;35:212-24.

10 Convertino VA, Armstrong LE, Coyle EF, et al. American college of sports medicine position stand: exercise and fluid replacement. Med Sci Sports Exerc 1996;28:i-vii.

11 Kulka TJ, Kenney WL. Heat balance limits in football uniforms. How different uniform ensembles alter the equation. Phys Sportsmed 2002;30:1-1 1.

12 Mathews D K, Fox EL, Tanzi D. Physiological responses during exercise and recovery in a football uniform. J Appl Physiol 1969;26:611-15.

13 Kenny WL, Lewis DA, Hyde DE, et al. Physiologically derived critical evaporative coefficients for protective clothing ensembles. J Appl Physiol 1987:63:1095-9

14 Wilmore $\mathbf{J H}$, Haskell W. Body composition and endurance capacity of professional football players. J Appl Physiol 1972;33:564-7.

15 Bale P, Colley E, Mayhew JL, et al. Anthropometric and somatotype variables related to strength in American football players. J Sports Med Phys Fitness 1994;34:383-9.

16 Broad EM, Burke LM, Cox GR, et al. Body weight changes and voluntary fluid intakes during training and competition sessions in team sports. Int J Sports Nutr 1996:6:307-20.

17 Pohl AP, O'Halloran MW, Pannall PR. Biochemical and physiological changes in football players. Med J Aust 1981;1:467-70.

18 Pyke AP, Hahn AG. Body temperature regulation in summer football. Sports Coach 1980;4:41-3.

19 Sawka MN, Pandolf KB. Effects of body water loss on physiological function and exercise performance. In: Gisolfi CV, Lamb DR, eds. Fluid homeostasis during exercise: perspectives in exercise science and sports medicine. Carmel, IN: Cooper Publishing Group, 1990;3:1-31.

20 Jackson AS, Pollack ML. Practical assessment of body composition. Phys Sportsmed 1985;13:76-90.

21 Dubois D, Dubois EF. A formula to estimate the approximate surface area if height and weight be known. Arch Int Med 1916;17:863-71.

22 Dill DB, Costill DL. Calculation of percentage changes in volumes of blood, plasma, and red cells in dehydration. J Appl Physiol 1974;37:247-8.

23 Shirreffs SM, Taylor AJ, Maughan RJ. Post-exercise rehydration in man: effects of volume consumed and drink sodium content. Med Sci Sports Exerc 1996;28:1260-71.

24 Maughan RJ, Leiper JB. Fluid replacement requirements in soccer. J Sports Sci 1994; 12:29-34.

25 Buono MJ, Sjoholm NT. Effect of physical training on peripheral sweat production. J Appl Physiol 1988;65:811-14

26 Irion GL. Responses of distance runners and sprinters to exercise in a hot environment. Aviat Space Environ Med 1987:58:948-53.

27 Mitchell DL, Senay C, Wyndam CH, et al. Acclimatization in a hot humid environment: energy exchange, body temperature and sweating. J Appl Physiol 1976;40:768-78.

28 Montain SJ, Latzka WA, Sawka MN. Control of thermoregulatory sweating is altered by hydration level and exercise intensity. J Appl Physiol 1995; 79:1434-9.

29 Havenith G, van Middendorp H. The relative influence of physical fitness, acclimatization state, anthropometric measures and gender on individual reactions to heat stress. Eur J Appl Physiol Occup Physiol 1990;61:429-7.

30 Armstrong LE, Szlyk PC, De Luca JP. Fluid-electrolyte losses in uniforms during prolonged exercise at 30 degrees C. Aviat Space Environ Med 1992;63:351-5.

31 Houmard JA, Egan PC, Johns RA, et al. Gastric emptying during $1 \mathrm{~h}$ of cycling and running at $75 \% \mathrm{VO}_{2 \max }$. Med Sci Sports Exerc 1991:23:320-5.

32 Zapiec C, Taylor AW. Muscle fibre composition and energy utilization in CFL football players. Can J Sport Sci 1979;4:140-2.

33 Noakes TD. Hyponatremia in distance athletes. Pulling the IV on the "dehydration myth". Phys Sportsmed 2000;28:71-6.

34 Noakes TD. The hyponatremia of exercise. Int J Sport Nutr 1992;2:205-28.

35 Shirreffs SM, Maughan RJ. Whole body sweat collection in humans: an improved method with preliminary data on electrolyte content. J Appl Physiol 1997:82:336-41.

36 Stofan JR, Zachwiega JJ, Horswill, et al. Sweat and sodium losses during practice in professional football players: field studies. Med Sci Sports Exerc 2002;34:S113.

37 Harrison, MH. Effects of thermal stress and exercise on blood volume in humans. Physiol Rev 1985;65:149-209.

38 Senay LC. Early response of plasma contents on exposure of working men to heat. J Appl Physiol 1978;44:166-70.

\section{COMMENTARY}

American football players present a unique fluid and salt balance problem as shown in this paper. The football uniform insulates the players and promotes large fluid volume losses. Replacing 9-15 litres of fluid each day is a difficult task and requires strict attention to daily weights and salt intake. Players with high sweat sodium 
concentrations will need to replace salt in their foods and fluids to avoid hyponatraemia, which can occur with the combination of large sweat sodium losses and high volume water replacement. Heat stroke football deaths usually occur in hot humid conditions such as those found in this study during the first few days of double sessions with the players in full equipment. The heat stress conditions outlined in the paper suggest that practice may have been modified to shorts and T-shirts without helmets on the hottest afternoons. Player safety considerations include weighing before and after practices and ensuring return to baseline weight between practices, fluid replacement during practices to approximate sweat losses, and salt replacement with extra dietary salt in the few days before and during the hot days of early season practice.

W O Roberts

University of Minnesota School of Medicine, Department of Family Practice, UMN Phalen Village, 1414 Maryland Avenue East, St Paul, MN 55106, USA; robert037@umn.edu

\section{ELECTRONIC PAGES}

\section{Online original articles}

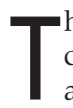
he following electronic only articles are published in conjunction with this issue of BJSM (see also pages 189 and 216)

\section{Effect of fluid ingestion on neuromuscular function during prolonged cycling exercise J-M Vallier, F Grego, F Basset, et al}

Objectives: To investigate the effects of fluid ingestion on neuromuscular function during prolonged cycling exercise.

Methods: Eight well trained subjects exercised for 180 minutes in a moderate environment at a workload requiring $\sim 60 \%$ maximal oxygen uptake. Two conditions, fluid (F) and no fluid (NF) ingestion, were investigated.

Results: During maximal voluntary isometric contraction $(\mathrm{MVC})$, prolonged cycling exercise reduced $(\mathrm{p}<0.05)$ the maximal force generating capacity of quadriceps muscles (after three hours of cycling) and root mean square (RMS) values (after two hours of cycling) with no difference between the two conditions despite greater body weight loss $(\mathrm{p}<0.05)$ in NF. The mean power frequency (MPF) for vastus lateralis muscle was reduced $(\mathrm{p}<0.05)$ and the rate of force development $(R F D)$ was increased $(p<0.05)$ only during NF. During cycling exercise, integrated electromyographic activity and perceived exertion were increased in both conditions $(p<0.05)$ with no significant effect of fluid ingestion.

Conclusions: The results suggest that fluid ingestion did not prevent the previously reported decrease in maximal force with exercise duration, but seems to have a positive effect on some indicators of neuromuscular fatigue such as mean power frequency and rate of force development during maximal voluntary contraction. Further investigations are needed to assess the effect of change in hydration on neural mechanisms linked to the development of muscular fatigue during prolonged exercise.

(Br J Sports Med 2005;39:el7) http://bjsm.bmjjournals.com/ cgi/content/full/39/1/el7

Drug use in English professional football

I Waddington, D Malcolm, M Roderick, et al

Objectives: To examine several issues related to drug use in English professional football. More particularly the project sought to gather data on: players' use of permitted supplements (mineral and vitamin pills and creatine); whether they sought advice, and if so from whom, about their use of supplements; their experience of and attitudes towards drug testing; their views on the extent of the use of banned performance enhancing and recreational drugs in football; and their personal knowledge of players who used such drugs.

Methods: With the cooperation of the Professional Footballers Association (PFA), reply paid postal questionnaires were delivered to the home addresses of all 2863 members of the PFA. A total of 706 questionnaires were returned, a response rate of just under $25 \%$.

Results: Many players use supplements, although almost one in five players does so without seeking qualified professional advice from anyone within the club. Blood tests are rarely used to monitor the health of players. One third of players had not been tested for drugs within the preceding two years, and $60 \%$ felt that they were unlikely to be tested in the next year. The use of performance enhancing drugs appears to be rare, although recreational drugs are commonly used by professional footballers: $6 \%$ of respondents indicated that they personally knew players who used performance enhancing drugs, and $45 \%$ of players knew players who used recreational drugs.

Conclusions: There is a need to ensure that footballers are given appropriate advice about the use of supplements in order to minimise the risk of using supplements that may be contaminated with banned substances. Footballers are tested for drugs less often than many other elite athletes. This needs to be addressed. The relatively high level of recreational drug use is not reflected in the number of positive tests.

This suggests that many players who use recreational drugs avoid detection. It also raises doubts about the ability of the drug testing programme to detect the use of performance enhancing drugs.

(Br J Sports Med 2005;39:el8) http://bjsm.bmjjournals.com/ cgi/content/full/39/1/el8 